\title{
Uji Resistensi Bakteri Escherichia Coli dari Sungai Boyong Kabupaten Sleman terhadap Antibiotik Amoksisilin, Kloramfenikol, Sulfametoxasol, dan Streptomisin
}

\author{
Hadi Sasongko \\ Progam Studi Pendidikan Biologi, Universitas Ahmad Dahlan \\ Kampus III, Jl. Prof. Dr. Soepomo, SH, Yogyakarta, 55164 Indonesia \\ surat elektronik: suhad72@ymail.com
}

\begin{abstract}
ABSTRAK
Resistensi mikrobia merupakan masalah yang serius dihadapi oleh ahli-ahli mikrobiologi kesehatan. Hal ini menimbulkan masalah yang menyebabkan antibiotika menjadi tidak berkhasiat bagi penyembuhan penyakit infeksi, perawatan menjadi lebih lama, dan biaya perawatan menjadi lebih tinggi. Penelitian ini dilakukan bertujuan untuk mengetahui resistensi bakteri SE. Coli yang diisolasi dari air sungai dan air rumah tangga sepanjang Sungai Code wilayah Kabupaten Sleman terhadap antibiotika amoksisilin, kloramfenikol, sulfametoxasol, dan streptomisin.

Isolasi $E$. coli dari sumber air sungai dan air rumah tangga dilakukan dengan cara taburan menggunakan medium kromogenik TBX, sedangkan uji resistensi menggunakan metode difusi padat cara Kirby Bauer yang dimodifikasi menngunakan medium Mueller Hinton Agar (MHA). Inokulasi isolat E.coli pada medium MHA dilakukan secara apus menggunakan kapas kidi streril, selanjutnya diletakkan disk antibiotika amoksisilin, kloramfenikol, sulfametoxasol, dan eritromisin di atasnya. Inkubasi dilakukan pada $37{ }^{\circ} \mathrm{C}$ selama 24 jam. Bakteri dapat dikatakan resisten, intermediet ataupun sensitif dengan mengukur zona hambat pada media uji, kemudian membandingkannya dengan Tabel Interpretasi Zona Hambat Standar dari BSAC version 8, January 2009.

Dari hasil penelitian menunjukkan bahwa : Isolat bakteri E. coli dari air sungai dan air rumah tangga sepanjang Sungai Code wilayah Sleman telah resisten terhadap antibiotik, khususnya amoksisilin dan streptomisin. Hasil uji resistensi memperlihatkan untuk amoksisilin 80\% dan $66.7 \%$, Kloramfenikol : $20 \%$ dan $6.7 \%$; Sulfametoxasol : $33.3 \%$ dan $46.7 \%$, serta streptomisin $73.3 \%$ dan $86.7 \%$.
\end{abstract}

Kata kunci: Resistensi, E. coli, Sungai Boyong, Air rumah tangga, Antibiotika

\section{Pendahuluan}

Kotaminasi air tanah oleh tinja manusia maupun hewan merupakan masalah kesehatan yang serius karena sebagian besar penduduk di Indonesia masih menggunakan golongan air tercemar untuk keperluan sehari-hari. Di bidang mikrobiologi air, beberapa mikroorganisme tertentu khususnya bakteri, kehadirannya dapat digunakan sebagai parameter atau indikator alami terhadap timbulnya pencemar organik. Mikroorganisme yang paling banyak hidup di air adalah Coliform dan Coli tinja (Jawet et al., 200I). Coliform dan Coli tinja merupakan kelompok bakteri yang digunakan sebagai indikator adanya polusi dan kondisi sanitasi yang tidak baik terhadap air minum, makanan, susu dan produk susu (Lay. I992).

Indonesia sebagai negara berkembang menghadapi banyak masalah kesehatan terutama peningkatan penyakit berbasis lingkungan. Salah satu dari penyakit berbasis lingkungan adalah penyakit diare. (Depkes RI, 2003). Di Indonesia angka kesakitan diare pada semua umur masih mencapai 300 per 1000 penduduk. Angka kematian diare pada semua umur mencapai 54 per I00.000 penduduk (Depkes RI, 200I). Penyakit diare hingga kini masih merupakan salah satu penyakit utama pada bayi dan anak di Indonesia. Diperkirakan angka kesakitan berkisar antara I50-430 per seribu setahunnya (FKUI, 2002). Menurut Survei Kesehatan Rumah Tangga, Departemen Kesehatan RI Tahun I996, I2\% penyebab kematian adalah diare. Disebutkan, akibat diare dari 1000 bayi, 70 bayi meninggal dunia sebelum merayakan hari ulang tahunnya yang pertama.

Kasus diare di Kota Yogyakarta, dari Januari hingga April 2007 tercatat 3.958 penderita. Dilaporkan pada bulan Januari jumlah penderita diare mencapai I.486 orang, Februari 967 orang, Maret 804 orang, dan April 
- Mei, 701 kasus. Menurut Dinas Kesehatan Kabupaten Sleman (2007), angka kematian bayi di Daerah Istimewa Yogyakarta tahun 2006 sebesar 20 per 1000 kelahiran hidup, 66\% kematian tersebut dikarenakan diare. Menurut profil Puskesmas Ngaglik I tahun 2006, di Puskesmas Ngaglik I tercatat kejadian diare pada bayi umur I bulan sampai kurang dari I tahun terdiri atas 26 kasus, kejadian diare pada anak umur I-4 tahun terdiri dari 67 kasus. Menurut Laporan Kasus Kesakitan Puskesmas Ngaglik II di Puskesmas Ngaglik II tercatat kejadian diare pada bayi umur I bulan sampai kurang dari I tahun terdiri dari 4 I kasus, kejadian diare pada anak umur I-4 tahun terdiri dari II5 kasus. Adapun antibiotik yang digunakan oleh Puskesmas untuk mengobati penyakit diare tersebut adalah antibiotik kotrimoksasol sedangkan antibiotik yang banyak dikonsumsi berdasarkan data dari apotek adalah amoksisilin.

Walaupun penanganan penyakit diare telah mengunakan antibiotik yang direkomendasikan oleh Puskemas atau Instansi Kesehatan tetapi pada kenyataannya jumlah kasus kejadian penyakit diare ada kecenderungan meningkat. Hal ini dapat disebabkan oleh banyak hal, selain masalah sanitasi, penyebab lain adalah kemungkinan telah terjadinya resistensi bakteri penyebab diare terhadap antibiotik. Salah satu bakteri penyebab penyakit diare adalah Escherichia coli. Bakteri ini adalah bakteri kolon manusia atau hewan berdarah panas yang akan dikeluarkan bersama tinja (Tjaniadi, et al., 2003).

Penggunaan agen-agen antimkrobial seringkali malah memunculkan resistensi multi-obat pada mikroorganisme (Prats, et al., 2003). Masalah resistensi saat ini telah menjadi permasalahan global. Beberapa bakteria, misalnya Klebsiella pnemoniae memperlihatkan peningkatan resistensi terhadap cephalosporin. Selain itu resistensi terhadap golongan quinolon juga memperlihatkan kecenderungan yang meningkat pada strain-strain E. coli yang diisolasi dari urin (Kadir dan Nasimuzzaman, 200I).

Pada beberapa kasus, pathogen justru menjadi resisten terhadap semua obat anti infeksi, sehingga akan semakin mempersulit upaya terapi berikutnya (Wals, 2005). Pada saat ini, fenomena resistensi antibiotik tidak hanya terbatas di lingkungan rumahsakit dan infeksi nosokomial saja, tetapi sudah tersebar ke populasi masyarakat luas (Ambe, et al., 200I).

Perkembangan resistensi terhadap antibiotik perlu dipantau agar dalam pengobatan penyakit diare dengan antibiotik dapat dilakukan pemilihan dan dosis antibiotik secara tepat. Resistensi antibiotika telah menjadi perhatian para tenaga medis dalam upaya kesejahteraan generasi penerus bangsa ini (Pudjarwoto, 2002). Dari kasus peningkatan jumlah penderita diare di Yogyakarta tersebut, kemungkinan juga telah terjadi fenomena resistensi bakteri penyebab diare. Untuk itu perlu/penting untuk dilakukan penelitian, khususnya terhadap bakteri E.coli yang diisolasi dari badan-badan air, khususnya Sungai Code yang melintasi wilayah Sleman, Kodya Yogyakarta, dan bantuk serta sumursumur penduduk yang terdapat di sepanjang aliran Sungai Code apakah sudah resisten terhadap antibiotik yang selama ini diberikan ke penderita diare atau masih sensitip terhadap antibiotik tersebut. Sebagai tahap awal dalam penelitian ini akan diisolasi $E$. coli resisten dari Sungai Code yang melalui wilayah kapubapten Sleman.

\section{Metode Penelitian}

\section{Alat dab Bahan}

I. Alat yang digunakan antara lain: botol sampel air, tabung reaksi dan raknya, cawan petri, becker glass, gelas ukur, ose bulat, pinset, pipet ukur, mikropipet, kapas steril, autoklaf, oven, inkubator, dan lampu bunzen.

2. Bahan yang digunakan antara lain: Bakteri Escherichia coli yang diisolasi dari air sungai di 15 titik dan air yang diambil dari rumah penduduk di sepanjang sungai Code di Kecamatan Pakem dan Ngaglik Kabupaten Sleman. Media untuk pertumbuhan bakteri E. coli adalah media TBX (trypton bile $\mathrm{x}$ glucoronide), nutrient agar (NA), dan media Mueller

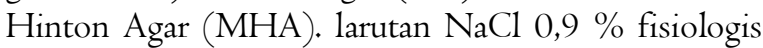
steril dan disk antibiotik : Amoksisilin 30 l, Kloramfenikol 30 , Streptomisin I0 $\mu$ dan Sulfametoksazol $25^{\mu \mathrm{l}}$ dari Oxoid.

\section{Cara Kerja}

I. Sterilisasi alat dan bahan Alat-alat gelas disterilisasi dalam dalam oven dan dipanaskan pada suhu I50-I700C selama kurang lebih I20 menit. Bahan-bahan dan media disterilisasi menggunakan autoklaf pada suhu I2IO C selama I5 menit.

2. Pengambilan Sampel

Sampel diambil dari air sungai Boyong di wilayah kapupaten Sleman di I5 titik yang dipilih secara acak,tiap titik diambil 2 sampel air sungai menggunakan botol sampel steril.

3. Penanaman Bakteri

Sampel ditanam pada media TBX trypton bile $x$ glucoronide) 24-30 jam pada suhu 370 C. Setelah diinkubasi dilihat ada atau tidaknya pertumbuhan koloni bakteri yang berwarna biru atau biru-hijau. Jika pada media terlihat adanya pertumbuhan koloni bakteri tersebut bias dipastikan bahwa koloni adalah Escherichia coli.

4. Identifikasi Bakteri

Identifikasi bakteri dilakukan dengan melihat warna koloni. JIka koloni terlihat berwarna biru atau biruhijau dipastikan bahwa koloni tersebut adalah Escherichia coli.

5. Pembuatan stok bakteri

Diambil satu ose koloni bakteri hasil identifikasi yang dipastikan Escherichia coli dan goreskan pada nutrient agar miring kemudian diinkubasi pada suhu $370 \mathrm{C}$ 
selama 24 jam. Disimpan sebagai stok Escherichia coli untuk uji selanjutnya; penggantian stok dilakukan 2 minggu sekali.

6. Uji Resistensi bakteri metode Kirby-Bauer

Dari stok bakteri Escherichia coli diambil 4-5 koloni bakteri dengan ose bulat diinokulasikan kedalam I ml BHI dan diinkubasi selama 4-8 jam pada suhu $37^{\circ} \mathrm{C}$. Ditambah aquades steril sampai kekeruhannya sama dengan kekeruhan standart McFarland $\left(10^{8} \mathrm{CFU} / \mathrm{ml}\right)$ kemudian diencerkan lagi dengan $\mathrm{IO} \mathrm{ml} \mathrm{NaCl} 0,9 \%$ fisiologis steril sampai konsentrasi bakteri $10^{6}$ $\mathrm{CFU} / \mathrm{ml}$. Media yang dipakai adalah agar Mueller Hinton pada cawan petri. Kapas lidi steril dicelupkan ke dalam suspensi bakteri lalu ditekan-tekan pada dinding tabung sehingga kapasnya tidak terlalu basah, kemudian dioleskan pada permukaan Media Agar Mueller Hinton hingga rata. Disk antibiotik (Amoksisilin $30^{\mu \mathrm{l}}$, Kloramfenikol $30^{\mu \mathrm{l}}$, Streptomisin I0 $\mu \mathrm{l}$ dan Sulfametoksazol $25 \mu \mathrm{l}$ ) diletakkan di atasnya, diinkubasi pada suhu $37^{\circ} \mathrm{C}$ selama I8-24 jam. Hasilnya dibaca dengan cara mengukur diameter zona jernih di sekitar disk antibiotik menggunakan penggaris. Hasil yang diperoleh dibandingkan dengan table standar uji kepekaan antibiotik dari Oxoid (1988).

\section{Hasil dan Pembahasan}

Isolasi dan identifikasi bakteri yang diperoleh dari sungai Boyong, diperoleh data bahwa sampel dari I5 titik yang diambil, semua positip terdapat Escherichia coli. $\mathrm{Hal}$ ini dapat diduga bahwa sungai Boyong dari data miktobiologis merupakan badan air tempat berbagai aktivitas warga membuang berbagai bahan sisa, utamanya adalah kotoran. Escherichia coli merupakan indikator utama pencemaran air oleh kotoran hewan berdarah panas, termasuk manusia.

Pada penelitian ini isolasi dan identifikasi E. coli menggunakan medium TBX, karena medium ini merupakan medium selektif untuk isolasi dan identifikasi E.coli. Hal ini dimungkinkan karena terdapat agen kromogenik $\mathrm{x}$-glukoronida yang berfungsi penting untuk mendeteksi enzim glukoronidase. Keberadaan enzim $\beta$ D-glukoronidase sangat spesifik uyang dapat digunakan untuk membedakannya dengan Enterobactwriaceae yang lain, utamanya bakteri coliform (Acumedia, 2009). Selsel E.coli menyerap x-glukoronida dan enzim intraseluler glukoronidase memutus ikatan antara gugus kromofor dan glukorronida. Pelepasan gugus kromofor inilah yang menyebabkan warna koloni menjadi biru atau biru kehijauan. Adanya garam empedu dalam medium berfungsi untuk menghambat mikroorganisme gram positif, sehingga tidak akan tumbuh

Pada penelitian ini, antibiotika yang digunakan adalah amoksisilin $30 \mu \mathrm{g}$, kloramfenikol $30 \mu \mathrm{g}$, sulfametoxasol $25 \mu \mathrm{g}$, dan streptomisin $I O \mu g$ yang dilakukan dengan cara menanamkan ke-empat disk antibiotika diatas kedalam media Mueller Hinton (MH) yang sebelumnya sudah ditanami bakteri $E$. coli.

Hasil uji sensitivitas bakteri SE. coli terhadap antibiotika yang dicobakan menunjukkan adanya hambatan pertumbuhan bakteri oleh antibiotika, karena disekitar disk antibiotika terlihat zona jernih. Bila bakteri E. coli sudah resisten tidak terlihat lingkaran bening disekitar disk antibiotika, atau zona jernih di sekitar disk memiliki diameter di bawah nilai ambang yang disyaratkan berdasar Zona Diameter Standar pada Table I.

Tabel I. Hasil Uji Interpretasi Kepekaan E. coli yang Diisolasi dari Air Sungai dan Air Rumah Tangga Sepanjang Sungai Code Wilayah Sleman terhadap Antibiotik Amoksisilin, Kloramfenikol, Sulfometoxasol, dan Streptomisin

\begin{tabular}{|c|c|c|c|c|c|c|c|c|c|}
\hline Lokasi & $\begin{array}{c}\text { Titik } \\
\text { sampel }\end{array}$ & \multicolumn{2}{|c|}{ Amoksisilin } & \multicolumn{2}{|c|}{ Kloramfenikol } & \multicolumn{2}{|c|}{ Sulfometoxasol } & \multicolumn{2}{|c|}{ Streptomisin } \\
\hline \multirow{16}{*}{ Air sungai } & & $(\mathrm{mm})^{\mathrm{ZH}}$ & ptsi ${ }^{\text {Int }}$ & $(\mathrm{mm})^{\mathrm{ZH}}$ & $\begin{array}{ll} & \text { Intpt } \\
\text { si } & \end{array}$ & $(\mathrm{mm})^{\mathrm{ZH}}$ & ptsi ${ }^{\text {Int }}$ & $(\mathrm{mm})^{\mathrm{ZH}}$ & si $\quad$ Intpt \\
\hline & I & 7.0 & $\mathrm{R}$ & I5.5 & I & I5.0 & I & 9.5 & $\mathrm{R}$ \\
\hline & 2 & 6.0 & $\mathrm{R}$ & I0.5 & $\mathrm{R}$ & 9.5 & $\mathrm{R}$ & 8.0 & $\mathrm{R}$ \\
\hline & 3 & 9.0 & $\mathrm{R}$ & I8.5 & $S$ & I8.5 & $S$ & I6.5 & $S$ \\
\hline & 4 & 6.0 & $\mathrm{R}$ & 9.0 & $\mathrm{R}$ & I8.5 & $S$ & I I.O & $\mathrm{R}$ \\
\hline & 5 & 6.0 & $\mathrm{R}$ & I7.0 & I & 6.0 & $\mathrm{R}$ & 9.0 & $\mathrm{R}$ \\
\hline & 6 & I3.5 & I & I6.0 & I & I8.0 & $S$ & I4.0 & $S$ \\
\hline & 7 & 6.0 & $\mathrm{R}$ & $\mathrm{I} 3.0$ & I & I2.0 & I & I I.0 & $\mathrm{R}$ \\
\hline & 8 & 7.5 & $\mathrm{R}$ & I4.5 & I & 7.5 & $\mathrm{R}$ & I0.5 & $\mathrm{R}$ \\
\hline & 9 & 6.0 & $\mathrm{R}$ & I3.5 & I & II.0 & $\mathrm{R}$ & 7.0 & $\mathrm{R}$ \\
\hline & I0 & 7.0 & $\mathrm{R}$ & 20.0 & $S$ & I5.0 & I & 8.0 & $\mathrm{R}$ \\
\hline & II & 6.0 & $\mathrm{R}$ & I9.0 & $S$ & I6.5 & $S$ & 8.0 & $\mathrm{R}$ \\
\hline & $\mathrm{I} 2$ & 6.0 & $\mathrm{R}$ & II.5 & $\mathrm{R}$ & 6.0 & $\mathrm{R}$ & 8.0 & $\mathrm{R}$ \\
\hline & $\mathrm{I3}$ & 20.5 & $\mathrm{~S}$ & 25.5 & $S$ & 21.0 & $S$ & I5.5 & $S$ \\
\hline & $\mathrm{I} 4$ & 6.0 & $\mathrm{R}$ & 21.5 & $S$ & I3.5 & I & 8.0 & $\mathrm{R}$ \\
\hline & I5 & 19.0 & $S$ & 25.5 & $S$ & 23.0 & $S$ & I3.0 & $S$ \\
\hline \multirow{7}{*}{$\begin{array}{l}\text { Air rumah } \\
\text { tangga }\end{array}$} & I & I4.0 & I & I6.5 & I & I4.0 & I & I0.0 & $\mathrm{R}$ \\
\hline & 2 & I6.0 & $S$ & 22.0 & $S$ & I9.0 & $S$ & I3.0 & $S$ \\
\hline & 3 & I8.5 & $S$ & 22.5 & $S$ & I5.0 & I & 9.5 & $\mathrm{R}$ \\
\hline & 4 & I8.0 & $S$ & I4.5 & I & I9.0 & $S$ & I0.0 & $\mathrm{R}$ \\
\hline & 5 & 6.0 & $\mathrm{R}$ & 21.0 & $S$ & I9.5 & $S$ & 7.5 & $\mathrm{R}$ \\
\hline & 6 & 6.0 & $\mathrm{R}$ & I2.0 & $S$ & 7.0 & $\mathrm{R}$ & 7.0 & $\mathrm{R}$ \\
\hline & 7 & 6.0 & $\mathrm{R}$ & 22.5 & $S$ & 20.5 & $S$ & I I.0 & $\mathrm{R}$ \\
\hline
\end{tabular}




\begin{tabular}{|c|c|c|c|c|c|c|c|c|c|}
\hline \multirow[t]{2}{*}{ Lokasi } & \multirow{2}{*}{$\begin{array}{c}\text { Titik } \\
\text { sampel } \\
8 \\
\end{array}$} & \multicolumn{2}{|c|}{ Amoksisilin } & \multicolumn{2}{|c|}{ Kloramfenikol } & \multicolumn{2}{|c|}{ Sulfometoxasol } & \multicolumn{2}{|c|}{ Streptomisin } \\
\hline & & 6.0 & $\mathrm{R}$ & I4.5 & I & II.0 & $\mathrm{R}$ & I0.0 & $\mathrm{R}$ \\
\hline & 9 & $3 \mathrm{I} .5$ & $S$ & 23.5 & $S$ & I5.0 & I & I3.5 & $S$ \\
\hline & 10 & 6.0 & $\mathrm{R}$ & 20.5 & $S$ & 6.0 & $\mathrm{R}$ & 6.0 & $\mathrm{R}$ \\
\hline & II & 6.0 & $\mathrm{R}$ & 26.0 & $S$ & 10.0 & $\mathrm{R}$ & 10.0 & $\mathrm{R}$ \\
\hline & I2 & 6.0 & 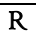 & 21.5 & $S$ & 22.0 & $\mathrm{~S}$ & II.0 & $\bar{R}$ \\
\hline & I3 & 6.0 & $\mathrm{R}$ & 21.0 & $S$ & 9.0 & $\mathrm{R}$ & I2.0 & $\mathrm{R}$ \\
\hline & I4 & 6.0 & $\mathrm{R}$ & I2.0 & $\mathrm{R}$ & 6.0 & $\mathrm{R}$ & 7.5 & $\mathrm{R}$ \\
\hline & I5 & 6.0 & $\mathrm{R}$ & 18.0 & $S$ & II.0 & $\mathrm{R}$ & II.0 & $\mathrm{R}$ \\
\hline
\end{tabular}

Keterangan : ZH:zona hambat ; Intptsi : interpretasi; R : resisten, I : intermedier, S : sensitip

Hasil pengukuran uji sensitivitas dapat dilihat pada Tabel I. Sedangkan prosentase resistensi dapat dilihat pada Tabel 2.

Tabel 2. Persentase Resitensi E. coli terhadap Antibiotika.

\begin{tabular}{|l|l|c|c|c|}
\hline Lokasi Sampel & Nama Antibiotika & Jumlah Sampel & Jumlah Sampel Resisten & \% Resistensi \\
\hline \multirow{4}{*}{ Air sungai Code } & Amoksisilin & I5 & I2 & 80.0 \\
\cline { 2 - 5 } & Kloramfenikol & I5 & 3 & 20.0 \\
\cline { 2 - 5 } & Sulfametoxasol & I5 & 5 & 33.3 \\
\cline { 2 - 5 } & Streptomisin & I5 & II & 73.3 \\
\hline \multirow{4}{*}{ Air rumah tangga } & Amoksisilin & I5 & I0 & 66.7 \\
\cline { 2 - 5 } & Kloramfenikol & I5 & I & 6.7 \\
\cline { 2 - 5 } & Sulfametoxasol & I5 & 7 & 46.7 \\
\cline { 2 - 5 } & Streptomisin & I5 & I3 & 86.7 \\
\hline
\end{tabular}

Berdasarkan data-data tersebut di atas sebagian besar isolate E. coli yang diisolasi dari air Sungai Code wilayah Sleman maupun dari air rumah tanggag sepanjang aliran air Sungai Code telah menunjukkan kecenderungan resisten terhadap kelima antibiotika yang diujikan, yaitu amoksisilin, kloramfenikol, sulfametoxasol, dan streptomisin..

Dari Tabel 2 menunjukkan bahwa bakteri E. coli telah mengalami resistensi terhadap antibiotika amoksisilin sebesar $80 \%$ dari isolate air sungai, dan $66.7 \%$ dari air rumah tangga. Prosentase resistensi ini termasuk tingai, terutama untuk isolat air sungai. Walaupun amoksisilin merupakan glonongan antibiotic berspektrum luas, nampaknya sudah perlu diwaspadai untuk penggunaanya terutama apabila terinfeksi oleh $E$. coli, khususnya untuk wilayah di sekitar Sungai Code wilayah Sleman. Antibiotik kloramfenikol memilki prosentase resistensi yang terkecil, baik dari isolat E.coli dari air Sungai Code (20\%) maupun isolate E.coli dari air rumah tangga (6.7\%). Secara pennggunaan, antibiotik ini masih mampu digunakan secara efektif terhadap $E$. coli, namun perlu diwaspadai terutama intuk lokasi wilayah 2, 3, dan I2 untuk air sungai dan wilayah I4 untuk air rumah tangga.

Prosentase resistensi antibiotic Sulfametoxasol cukup tinggi, yaitu $33.3 \%$ untuk isolate E. coli air sungai dan $46.7 \%$ air rumah tangga. Aktivitas antibakteri sulfametoxasol bekerja pada dua tahap yang berurutan dalam reaksi enzimatik untuk membentuk asam tetrahidrofolat. Sulfametoxasol menghambat masuknya molekul PABA kedalam molekul asam folat dan trimetropim menghambat terjadinya reaksi reduksi dari dihidrofolat menjadi tetrahidrofolat. Frekuensi terjadinya resistensi terhadap kotrimoksazol lebih rendah dari pada terhadap masing-masing obat, karena mikroba yang resisten terhadap salah satu komponen masih peka terhadap komponen lainnya (Ganiswarna, 1995). Frekuensi terjadinya resistensi terhadap Sulfametoxasol perlu diwaspadai karena angkanya sudah mendekati $\% 05$, terutama untuk air rumah tangga yang kenungkinan juga digunakan warga untuk berbagai keperluan sehari-hari.

Antibiotik streptomisin menunjukkan prosentase resistensi yang sangat tinggi terutama untuk air rumah tangga (86\%) sedangkan air sungai tinggi (73.3\%). Streptomisin merupakan antibiotik yang bekerjanya adalah mengganggu sintesis protein, terutama di ribosom. Rendahnya sensitivitas E. coli terhadap streptomisin bisa disebabkan oleh degradasi ensimatik terhadap antibiotik tersebut, maupun permeabilitas membran yang menyebabkan antibiotik tidak dapat masuk ke dalam sel bakteri.

Hasil uji resistensi antibiotika isolat E. coli dari air sungai dan air rumah tangga di sepanjang Sungai Code wilayah Sleman terhadap antibiotik amoksisilin, kloramfenikol, sulfametoxasol, dan streptomisin menunjukkan kecenderungan resisten, terutama amoksisilin dan streptomisin. Untuk antibiotik kloramfenikol tingklat resistensinya relatif kecil, sehingga penggunaanya untuk infeksi E. coli masih efektip, sedangkan untuk ke empat antibiotik yang lain kecenderungan resistensi cukup tinggi, bahkan sangat tinggi untuk amoksisilin dan streptomisin. Banyak hal dapat berpengaruh, antara lainselain faktor perilaku pengguna, dan bebasnya orang dapat membeli antibiotik, juga kemungkinan oleh adanya reisitensi silang antar strain E. coli yang ada di alam, khususnya dari E. coli 
yang memiliki sifat resisten terhadap E. coli lain yang belum resisten. E. coli memiliki kemampuan untuk melakukan konjugasi antar strain secara alami untuk saling menukarkan beberapa sifat adaptifnya.

\section{Simpulan}

Isolat bakteri E. coli dari air sungai dan air rumah tangga sepanjang Sungai Code wilayah Sleman telah resisten terhadap antibiotik, khusunya amoksisilin dan streptomisin.

Hasil uji resistensi isolat bakteri E. coli dari lair sungai dan air rumah tangga sepanjang Sungai Code wilayah Sleman untuk amoksisilin $80 \%$ dan $66.7 \%$, Kloramfenikol: $20 \%$ dan $6.7 \%$; Sulfametoxasol: $33.3 \%$ dan $46.7 \%$, serta streptomisin $73.3 \%$ dan $86.7 \%$.

\section{Daftar Pustaka}

Acumedia. 2009. Trypton Bile X-Glukoronide (TBX) Medium (7692). Neogen Corporation. neogeninfo@neogen.com.

Ambe, Sampath, and Modak. 200I. In Vitro Evaluation of The Risk of Developing Bacterial Resistance to Antiseptics and Antibiotics Used in Medical Device. Journal of Antimicrobial Chemoteraphy. 47, 589 - 598

Anonim, 2002, Pedoman Sanitasi Rumah Sakit di Indonesia, I3I, I4I-I47, I6I-I72, Departeman Kesehatan Republik Indonesia, Jakarta.

Ganiswarna. I995, Farmakologi dan Terapi, Edisi IV, 57I583, Bagian Farmakologi Fakultas Kedokteran Universitas Indonesia, Jakarta.

German-Fattal. 2007. Bacterial Resistance : Changing Clinical Practice. Servier International - 22, rue Garnier - 92200 Neuilly-sur-Seine - France

Jawetz, E. : J. L. Melnick and E. A. Adelberg. $200 I$. Mikrobiologi Kedokteran,. Diterjemahkan oleh Bagian Mikrobiologi Fakultas kedokteran Universias Airlangga, 96-98, 223-235, Penerbit Salemba Medika, Jakarta.

Lay, dan Hastowo. 1992. Mikrobiologi. Penerbit Rajawali Press. Jakarta.

Tjaniadi, Lesmana, Subekti, Machpud, Komalarini, Santoso, Simanjuntak, Punjabi, Campbell, Alexander, Beecham, Corwi and Oyofo. 2003. Antimicrobial Resistance of Bacterial Pathogens Associated With Diarrheal Patients in Indonesia. Am. J. Trop. Med. Hyg., 68(6), pp. 666670

Wals, 2005. Antibiotics : Actions, Origins, Resistance. Nat. Prod. Rep. 22, $304-305$ 